\title{
Cardiac muscle apoptosis: a comparison of myocardium revascularization with and without cardiopulmonary bypass
}

Apoptose no músculo cardíaco: comparação na revascularização do miocárdio com e sem circulação extracorpórea

Diego Felipe GAIA, Rafael Saviolo MOREIRA, Magaly ARRAIS, Nivia Cristina Tot VINHOLA, Enio BUFFOLO, Ricardo Luiz SMITH

RBCCV 44205-641

\section{Abstract}

Objective: Inflammatory response and metabolic disturbances in coronary artery bypass grafting (CABG) with cardiopulmonary bypass (CPB) and without (OFF-PUMP) have been researched. Apoptosis in ischemic reperfusion and chronic disease models has been shown in recent studies. The objective of this study is to compare the apoptosis intensity detected in cardiac myocytes before and after CABG with and without cardiopulmonary bypass.

Method: Eighteen patients undergoing elective CABG were divided in two groups: the first group underwent cardiopulmonary bypasses and the second group did not Auricle myocardial samples were obtained at the beginning and at the end of the surgery. Specimens were examined for apoptosis using the TUNEL method.

Results: There was no significant difference between the two groups in the surgical, demographic and postoperative data. The number of grafts was statistically different. There was no significant difference between the numbers of cells undergoing apoptosis in the two groups at the beginning of the procedure. There was no significant difference in the number of cells undergoing apoptosis from the beginning to the end of CABG in the OFF-PUMP group. There was a significant difference between the number of cells undergoing apoptosis at the beginning and the end of the CABG in the CPB group $(\mathbf{p}<0.01)$.

Conclusion: The smaller number of cells undergoing apoptosis in the OFF-PUMP group is in accordance with published data that suggest CPB is capable of promoting cell lesion. Having shown that, another favorable argument can be added to the indication of the CABG without CPB.

Descriptors: Apoptosis. Cardiopulmonary bypass. Coronary artery bypass grafting.

Resumo

Introdução: A resposta inflamatória e os distúrbios metabólicos nas cirurgias de revascularização do miocárdio (RM) com e sem circulação extracorpórea (CEC) têm sido

Work performed in the Federal University of São Paulo - Escola Paulista de Medicina. Descriptive Anatomy and Topographic Department / Cardiovascular Surgery Department

Work presented at the $30^{\text {th }}$ National Congress of Cardiac Surgery, Goiânia, GO, April 2003.

Correspondence address: Diego Felipe Gaia. Universidade Federal de São Paulo - Escola Paulista de Medicina. Disciplina de Anatomia Descritiva e Topográfica. Rua Botucatu 740. Vila Clementino. São Paulo, SP, Brazil. Phone: (11) 5576-4261. Fax (11) 5571-7597. e-mail: gaia.morf@epm.br 
pesquisados. A apoptose vem sendo estudada em modelos de isquemia, reperfusão e processos crônicos. $O$ objetivo deste trabalho é comparar o grau de apoptose detectada em cardiomiócitos, antes e após a RM com e sem CEC.

Método: Dezoito indivíduos com indicação de RM, divididos em dois grupos (CEC e OFF-PUMP), sendo o primeiro (CEC) com o emprego da CEC e o segundo sem o auxílio desta (OFF-PUMP), tiveram coletadas biópsias da aurícula direita, ao início e ao término da operação. Os fragmentos foram submetidos à marcacão imunohistoquímica pelo método de TUNEL e à contagem das células em apoptose.

Resultados: Não houve diferença entre os grupos nos dados cirúrgicos, demográficos e pós-operatórios. O número de pontes foi estatisticamente diferente. Não houve diferença entre o número de células em apoptose nos grupos CEC e

\section{INTRODUCTION}

Comparisons of inflammatory responses and of metabolic imbalance in coronary artery bypass grafting $(\mathrm{CABG})$ with and without cardiopulmonary bypass (CPB) have been researched. Studies demonstrate the advantages in favor of the use of off-pump surgery, that is, without CPB, both in terms of the evolution and prognosis in correctly selected patients $[1,2]$

Cardiovascular surgery may trigger a systemic inflammatory response responsible for the dysfunction of organs, which is observed in patients after cardiovascular surgical procedures. Evidence suggests the involvement of varying mediators in this mechanism [3]

CPB, by itself, might induce apoptosis. Patients submitted to $\mathrm{CPB}$ have higher levels of fas and fas ligand expression [4]. The serum of patients who underwent CPB is also capable of inducing apoptosis in endothelial cell cultures [5].

Currently a new approach in investigations is being explored, the study of the process of apoptosis and its implications in several models of ischemia, ischemia/ reperfusion and chronic processes, in particular those involving cardiomyocytes [6].

The investigations try not only to identify the triggering mechanisms of the process, but also to create solutions capable of reducing the lesions caused by apoptosis and, consequently, strategies to reduce the loss of myocytes [6]

Apoptosis seems to be present in the human heart in varying conditions such as in heart failure, myocardial infarction, hibernating myocardium and it is induced during open heart surgery, where it can contribute to lesions provoked by ischemia/reperfusion as well as post-bypass renal failure and brain failure [7].

Apoptosis is a type of programmed cell death which has be described over the last decades as the main mechanism of cellular turnover to maintain a cell-population balance in
OFF-PUMP, ao início do procedimento. O número de células em apoptose não apresentou diferença significante entre o início e o término do procedimento no grupo OFF-PUMP. $O$ número de células em apoptose, ao início e ao término da operação, no grupo CEC apresentou diferença significante.

Conclusão: O menor número de células em apoptose encontrado no grupo OFF-PUMP condiz com dados da literatura que sugerem que a CEC é uma agressão à homeostase e capaz de gerar lesão celular. Deste modo, mais um argumento favorável pode ser agregado para a maior indicação de RM sem o uso de CEC.

Descritores: Apoptose. Ponte Cardiopulmonar. Revascularização Miocárdica.

all tissues. Contrary to other types of cell death, apoptosis presents with morphological and biochemica characteristics, which differentiate it from types of, cell death such as necrosis [8]

Differently from necrosis, the process of apoptosis is active, depending on the energy consumption and it is dubbed as a precise regulating mechanism. Apoptosis plays a fundamental role in the regulation of cellular proliferation, whether in mature or in developing tissues [9-11]. Although the process might be triggered by genetically established triggers, other phenomenon and stimuli can activate it, contributing to the physiopathology of several processes of diseases $[12,13]$

Initially described in 1972 by KERR et al. [9], apoptosis can be identified by molecular and biochemical characteristics, however, morphological aspects observed with electronic microscopes are the gold standard for its identification [7]

Nevertheless, a biochemical characteristic, the internucleosomal fragment of DNA, allowed an immunocytochemical reaction to detect cells in apoptosis, based on specific markers of the 3'-hydroxyl termination of fragmented DNA, characteristics of cells in apoptosis, by the addition of digoxigenin nucleotides by Terminal Deoxynucleotidyl Transferase (TdT). This enzyme catalyzes the addition of deoxyribonucleotide-triphosphate to 3'-hydroxyl terminal portions of DNA fragments. After incubation with anti-digoxigenin peroxidase, the reaction is revealed by chromogenic reagents, such as diaminobenzidin which causes the formation of a brown precipitate at the site of the DNA breakpoint. This method commended by GAVRIELI et al. [14] in 1992, is known as TUNEL ("Terminaltransferase dUTP Nick End Labeling") and allows detection of the cells that are undergoing programmed cellular death.

However, the TUNEL method can sometimes not be completely specific in the marking of cells in apoptosis and, 
consequently, some cells in necrosis and even the DNA or RNA itself undergoing the repair process, can be positively marked. Even electrophoresis of DNA might not be completely specific to demonstrate the fragmentation characteristic of DNA, as many non-cardiomyocyte cells might be marked in the sample [15].

Although the TUNEL method is not the best manner to semi-measure apoptosis of the cardiac myocytes, it is one of our only tools. The frequency of positivity in several studies demonstrates the dependence on diverse factors, among which are the time of ischemia and the presence or not of reperfusion $[13,16]$.

Thus the aim of this work is to compare the degree of apoptosis detected in cardiomyocytes, before and after $\mathrm{CABG}$ with and without $\mathrm{CPB}$.

\section{METHOD}

The Research Ethics Committee of the institution approved the protocol of this study. Written consent was obtained from all the patients included in the study. Eighteen patients who underwent elective $\mathrm{CABG}, 9$ with $\mathrm{CPB}$ and 9 off-pump were selected. The use or not of CPB was determined by the experience of the surgical team as has previously been described [1].

Re-operations, chronic renal failure, immunosuppression and ejection fractions of less than $40 \%$ were considered exclusion criteria.

Demographic, surgical, post- and intra-operative data were collected.

Small samples of the right auricula of individuals in the study were collected for biopsy at the start and end (immediately before closure of the thoracic cage) phases of the operation, taking care to avoid possible ischemic areas caused by surgical manipulation such as at the site of CPB cannulae.

The fragments were immediately fixed in $10 \%$ buffered formalin. Fine 5-micrometer sections were placed on silanized glass slides. The paraffin was removed from the samples with xylol and re-hydrated with graduated concentrations of ethanol. Subsequently, the samples were permeablized with $\mathrm{K}$ proteinase and submitted to marking, according to the instructions of the kit used (QIA33 - Calbiochem). A counter-staining was made with methyl green. Negative controls were produced by excluding the TdT reaction.

Measurements were performed by two experienced 'blind' examiners using histological image acquisition software. The number of positively marked and the number of non-marked cells at an amplification of 200x in six random fields of view were counted on each slide, with one slide per pre-operative sample and another per post-operative sample.

The data were submitted to statistical analysis using the StatsDirect computer software. The Mann-Whitney and
Wilcoxon tests were utilized and a significance level of 5\% was used.

\section{RESULTS}

The individual characteristics researched did not demonstrate statistically significant differences between the two groups with the exception of the number of grafts, as is shown in Table 1.

The mean percentages of the positively marked cells using the TUNEL technique were as follows: Off-pump group preoperative $15.2 \%$, Off-pump group post-operative $=16.4 \%$, CPB group pre-operative $=10.2 \%$ and $\mathrm{CPB}$ group post-operative $=$ $20.4 \%$. In the Off-pump group there was no statistically significant difference between the samples collected at the start and end of the surgery ( $\mathrm{p}$-value $>0.99$ ). In the $\mathrm{CPB}$ group there was a significant difference between the pre- and post-operative groups $(\mathrm{p}$-value $=0.03)($ Figure 1$)$.

The number of positively marked cells per field of view in the four groups is demonstrated in Figure 2.

\section{COMMENTS}

This investigation demonstrated that the quantity of cells evidenced by immunocytochemical markers for apoptosis was significantly greater in the CPB postoperative group when compared with the CPB preoperative group and with the Off-pump post-operative group. These findings correspond with published results that report the induction of apoptosis by cardioplegic systems, ischemia and reperfusion and by systemic inflammatory response due to CPB.

The percentage of positively marked cells found by the reaction at the start of the operation in ischemic patients agrees with previous publications [17].

Studies suggest that reperfusion, but not ischemia, accelerates the apoptosis process and the fragmentation of DNA [18]. Isolation of the individual components responsible for the process seems a complicated task, as several mediators are implicated in different steps of the cascade that culminates in cellular destruction by apoptosis, frequently triggered by distinct mechanisms and routes [13]. Their delimitation is still not clear, as is the role of each of them and the exact location and mechanism of the action.

The choice of atrial fragment for the detection of apoptosis also seems appropriate as it is supposed that the phenomenon is the same in the entire heart [19].

The number of cells found in the atrial fragments might seem relatively high and some factors contribute to this finding. The use of $\mathrm{K}$ proteinase might increase the number of false positive cases marked in the TUNEL test by the liberation of endogen endonuclease [20]. The test might not be specific for apoptosis too and cells in necrosis could 
Table 1. Characteristics of the patients and operative variables for the CPB and OFF-PUMP groups (mean and standard deviation)

\begin{tabular}{|c|c|c|c|}
\hline & CP B & OFF PUMP & p-value \\
\hline Gender & & & NS \\
\hline Male & 7 & 5 & \\
\hline Female & 2 & 4 & \\
\hline Age & $64,17 \pm 11,17$ & $62,89 \pm 11,49$ & NS \\
\hline $\begin{array}{l}\text { Arterial Hypertension } \\
\text { Systemic Arterial (number) }\end{array}$ & 6 & 2 & NS \\
\hline Diabetes Mellitus (number) & 2 & 0 & NS \\
\hline Dyslipidemia (number) & 3 & 4 & NS \\
\hline Ejection fraction (\%) & $63,8 \pm 4,1$ & $62,2 \pm 5,9$ & NS \\
\hline Surgery time (min) & $324,3 \pm 54,2$ & $309,3 \pm 21,0$ & NS \\
\hline Tourniquet time (min) & NA & $33,9 \pm 7,5$ & NA \\
\hline CPB time (min) & $91,7 \pm 28,7$ & NA & NA \\
\hline Clamping time (min) & $62,0 \pm 22,5$ & NA & NA \\
\hline Number of grafts & $3,4 \pm 1,0$ & $2,2 \pm 0,7$ & S \\
\hline Days in ICU & $2,3 \pm 0,6$ & $2,2 \pm 0,7$ & NS \\
\hline Use of vasoactive drugs & 0 & 0 & NS \\
\hline OTI time (min) & $417,7 \pm 175,3$ & $326,1 \pm 129,5$ & NS \\
\hline
\end{tabular}

CPB - Cardiopulmonary Bypass

OTI - Orotracheal intubation

NA - Not applicable

NS - Without statistical significance (t-test)

$\mathrm{S}$ - Significant $\mathrm{p}$-value $=0.008$ (t-test)

ICU - Intensive Care Unit

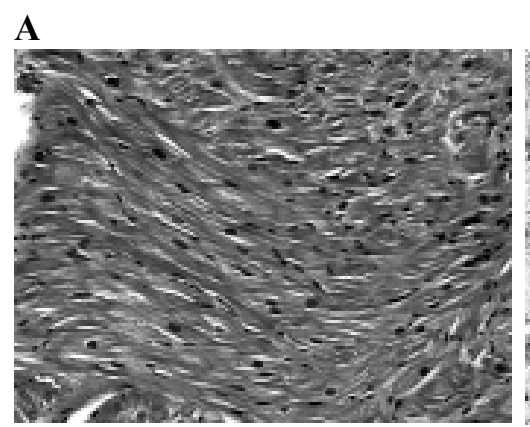

B

C

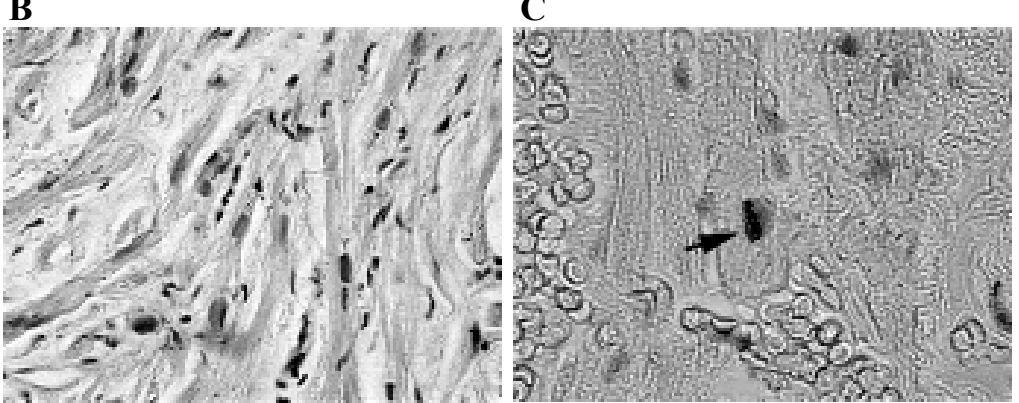

Fig. 1 - A- Hematoxylin and Eosin stain. 100X. Myocardium with a normal aspect. Pre-operative Off-Pump group. B - TUNEL. 200X. Preoperative Off-Pump group. Observe the absence marked nuclei. C-TUNEL.400X. Post-operative CPB group. Observe the marked nucleus (arrow). 


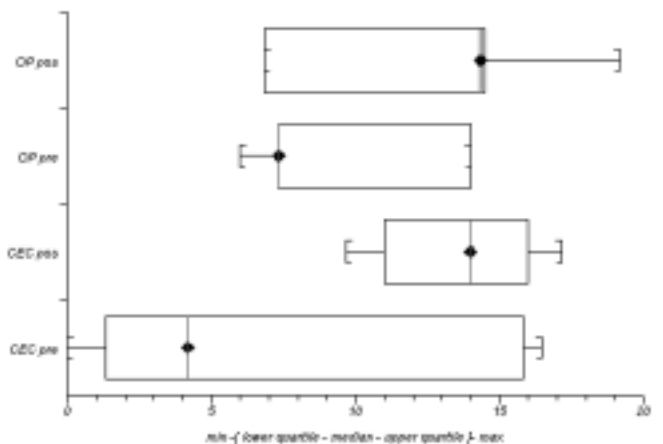

Fig. 2 - Number of marked cells per field of view in the different groups

OP post - Post-operative Off-pump group

OP pre - Pre-operative Off-pump group

$\mathrm{CPB}$ post - Post-operative CPB group

CPB pre - Pre-operative CPB group

OP pre versus OP post $-\mathrm{p}=0.38$ (Wilcoxon)

CPB pre versus CPB post $-\mathrm{p}=0.02 *$ (Wilcoxon)

OP pre versus CPB pre $-p=0.43$ (Mann-Whitney)

OP post versus CPB post $-\mathrm{p}=0.0002 *$ (Mann-Whitney)

be TUNEL-positive [13]. On the other hand, there is reported evidence of apoptosis without fragmentation of the DNA [21].

Another fact to be considered is that many noncardiomyocyte cells, such as endothelial cells, microphages, myofibroblasts and neutrophil infiltration could be being marked and increasing the global cell count [13].

The test used in this study is not a definitive and exact manner to detect apoptosis and other forms of detection can be used in combination with it for a more precise estimation of the number of cardiomyocytes involved and subject to this phenomenon.

However, in our study, two groups were compared with similar characteristics and submitted to the same histological preparation and, thus, possibly subject to the same risks of overestimation of the number of positively marked cells by the TUNEL technique. Thus, the difference between the groups should be maintained if other more specific methods of measurement are employed.

Hence, this is not a conclusive study, however we suggest that the use of $\mathrm{CPB}$ in $\mathrm{CABG}$ surgeries is capable of inducing apoptosis in a greater number of cells, when compared to Off-pump CABG.

To reduce apoptosis seems to be a good way of reducing cardiac lesions provoked by ischemia/reperfusion and systemic inflammatory responses to CPB [7]. However, the correct manner of intervention in the process still needs to be better elucidated, in a way that only the deleterious effects can be lessened and the physiologic function preserved.

The findings point to further evidence of the aggression that $\mathrm{CPB}$ can create in relation to homeostasis of the individual. Consequently, a favorable factor can be added for the greater implementation of Off-pump CABG surgery, as this investigation supplies data implicating the use of the heart-lung machine and the exposition of human blood to non-endothelium surfaces to deleterious effects of the physiopathology of the systemic response in Off-pump CABG surgeries.

\section{BIBLIOGRAPHIC REFERENCES}

1. Buffolo E, de Andrade JCS, Branco JN, Teles CA, Aguiar LF, Gomes WJ. Coronary artery bypass grafting without cardiopulmonary bypass. Ann Thorac Surg 1996; 61:63-6.

2. Buffolo E. Why is "off-pump" coronary artery bypass grafting better? Heart Surg Forum 2002; 5:154-6.

3. Brasil LA, Gomes WJ, Salomao R, Buffolo E. Inflammatory response after myocardial revascularization with or without cardiopulmonary bypass. Ann Thorac Surg 1998; 66:56-9.

4. Kawahito K, Misawa Y, Fuse K. Transient rise in serum soluble Fas (APO-1/CD95) in patients undergoing cardiac surgery. Artif Organs 2000; 24:628-31.

5. Aebert H, Kirchner S, Keyser A, Birnbaum DE, Holler E, Andreesen R et al. Endothelial apoptosis is induced by serum of patients after cardiopulmonary bypass. Eur J Cardiothorac Surg 2000; 18:589-93.

6. Haunstetter A, Izumo S. Future perspectives and potential implications of cardiac myocyte apoptosis. Cardiovasc Res $2000 ; 45: 795-801$

7. Valen G. The basic biology of apoptosis and its implications for cardiac function and viability. Ann Thorac Surg 2003; 75:S656-60. 
8. Majno G, Joris I. Apoptosis, oncosis, and necrosis: an overview of cell-death. Am J Pathol 1995; 146:3-15.

9. Kerr JF, Wyllie AH, Currie AR. Apoptosis: basic biological phenomenon with wide-ranging implications in tissue kinetics. Br J Cancer 1972; 26:239-57.

10. Steller H. Mechanisms and genes of cellular suicide. Science $1995 ; 267: 1445-9$.

11. Savill J. Apoptosis in disease. Eur J Clin Invest 1994; 24:715-23.

12. Sabbah HN. Apoptotic cell death in heart failure. Cardiovasc Res 2000; 45:704-12.

13. Yaoita H, Ogawa K, Maehara K, Maruyama Y. Apoptosis in relevant clinical situations: contribution of apoptosis in myocardial infarction. Cardiovasc Res 2000; 45:630-41.

14. Gavrieli Y, Sherman Y, Ben Sasson SA. Identification of programmed cell-death in situ via specific labeling of nuclear DNA fragmentation. J Cell Biol 1992; 119:493-501.

15. Knaapen MW, Davies MJ, De Bie M, Haven AJ, Martinet W, Kockx MM. Apoptotic versus autophagic cell death in heart failure. Cardiovasc Res 2001; 51:304-12.
16. Olivetti G, Quaini F, Sala R, Lagrasta C, Corradi D, Bonacina E et al. Acute myocardial infarction in humans is associated with activation of programmed myocyte cell death in the surviving portion of the heart. J Mol Cell Cardiol 1996; 28:2005-16.

17. Narula J, Haider N, Virmani R, DiSalvo TG, Kolodgie FD, Hajjar RJ et al. Apoptosis in myocytes in end-stage heart failure. N Engl J Med 1996; 335:1182-9.

18. Maulik N, Yoshida T, Das DK. Oxidative stress developed during the reperfusion of ischemic myocardium induces apoptosis. Free Radic Biol Med 1998; 24:869-75.

19. Schmitt JP, Schroder J, Schunkert H, Birnbaum DE, Aebert H. Role of apoptosis in myocardial stunning after open heart surgery. Ann Thorac Surg 2002; 73:1229-35.

20. Stahelin BJ, Marti U, Solioz L, Zimmermann H, Reichen J. False positive staining in the TUNEL assay to detect apoptosis in liver and intestine is caused by endogenous nucleases and inhibited by diethyl pyrocarbonate. Mol Pathol 1998; 51:204-8.

21. Sakahira H, Enari M, Nagata S. Cleavage of CAD inhibitor in CAD activation and DNA degradation during apoptosis. Nature 1998; 391:96-9. 